\title{
Bronchial hyperresponsiveness in lung transplant recipients: lack of correlation with airway inflammation
}

Pam Liakakos, Gregory I Snell, Christopher Ward, David P Johns, Tiffany L Bamford, Trevor J Williams, E Haydn Walters

\begin{abstract}
Background - Bronchial hyperresponsiveness (BHR) to methacholine has been reported to occur in most lung transplant recipients. BHR to physical stimuli such as exercise and non-isotonic aerosols has not been as extensively studied in this subject population. This report aims to assess the presence and degree of BHR to methacholine and hypertonic saline in stable lung transplant recipients and to relate it to the presence of airway inflammation. Methods - Ten patients undergoing bilateral sequential lung transplantation and six heart-lung transplant recipients, all with stable lung function, were recruited 66-1167 days following transplantation. Subjects underwent a methacholine challenge and bronchoscopy for sampling of bronchoalveolar lavage fluid, transbronchial and endobronchial biopsy tissues. Hypertonic saline challenge was performed six days later.
\end{abstract}

Results - Nine of the 16 transplant recipients had positive methacholine challenges (geometric mean $P_{20} 0.18 \mathrm{mg}$, interquartile range $0.058-0.509$ ) and three of these subjects also had positive hypertonic saline challenges $\left(\mathbf{P D}_{15}=2.3,33.0\right.$, and $51.5 \mathrm{ml}$ ). No clear relationship was found between BHR to either methacholine or hypertonic saline and levels of mast cells, eosinophils or lymphocytes in samples of biopsy tissue or lavage fluid. Conclusions - Most of the lung transplant recipients studied were responsive to methacholine and unresponsive to hypertonic saline. BHR was not clearly related to airway inflammation, suggesting an alternative mechanism for BHR following lung transplantation from that usually assumed in asthma.

(Thorax 1997;52:551-556)

Keywords: hyperresponsiveness, lung transplantation, inflammation.

Most studies investigating bronchial hyperresponsiveness (BHR) to methacholine in lung transplant recipients have found the majority of subjects to be hyperresponsive to methacholine, ${ }^{1-5}$ although there have been studies with negative results. ${ }^{6}$ Challenges with exercise $^{7}$ and dry air $^{6}$ were negative in lung transplant recipients, but a positive reaction to ultrasonically nebulised distilled water (USNDW) has been demonstrated. ${ }^{1}$

BHR is an observation widely described in the literature in relation to the pathophysiology underlying asthma. ${ }^{8-15}$ The presence of airway inflammation is increasingly accepted as underlying the BHR observed in asthmatic subjects. ${ }^{9-15}$ This has been extensively characterised in studies of biopsy tissue and bronchoalveolar lavage (BAL) fluid from asthmatic patients where eosinophils, mast cells, and $\mathrm{T}$ lymphocytes are likely to be key inflammatory cells. ${ }^{1112}$ In asthmatic subjects, while methacholine is thought to act directly on airway smooth muscle, "indirect" agents such as hypertonic saline may cause bronchoconstriction by the release of preformed mediators from degranulated inflammatory cells, especially mast cells. ${ }^{1617}$

Most of the lung transplant recipients in whom BHR has been noted were not known to have asthma prior to transplantation and did not receive lungs from an asthmatic donor. Such studies have generally speculated that BHR results from the denervation of the airways following transplantation leading to hypersensitivity of the smooth muscle through upregulation of muscarinic receptors. ${ }^{127}$ It has been suggested that subjects with bilaterally denervated lungs are more responsive to methacholine and histamine than subjects with unilaterally denervated lungs. ${ }^{3}$

The relationship between chronic rejection with airway inflammation and BHR after lung transplantation remains largely uncharacterised, with only semi-quantitative data relating to simple differential cell counts available. ${ }^{16}$ The lack of such data is surprising since changes in the airway are a likely hallmark of obliterative bronchiolitis, the most common cause of morbidity and mortality in lung transplant recipients beyond three months.

The aim of this study was to document the presence and degree of BHR to methacholine and hypertonic saline in stable double lung transplant recipients and to relate these physiological changes to the degree of airway inflammation observed. We hoped to gain insights into the specific cell types associated with different forms of BHR and to use this to determine whether BHR measurements could assist in the detection of uncontrolled airway inflammation in lung transplant recipients. 
Table 1 Patient characteristics

\begin{tabular}{|c|c|c|c|c|c|c|c|}
\hline \multirow{2}{*}{$\begin{array}{l}\text { Patient } \\
\text { no. }\end{array}$} & \multirow[t]{2}{*}{ Sex } & \multirow[t]{2}{*}{ Age } & \multirow{2}{*}{$\begin{array}{l}\text { Diagnosis prior } \\
\text { to transplantation }\end{array}$} & \multirow{2}{*}{$\begin{array}{l}\text { Transplantation } \\
\text { type }\end{array}$} & \multirow{2}{*}{$\begin{array}{l}\text { Days after } \\
\text { transplantation }\end{array}$} & \multicolumn{2}{|l|}{$F E V_{1}$} \\
\hline & & & & & & (l) & $(\%$ best $)$ \\
\hline 1 & $\mathrm{~F}$ & 32 & $\mathrm{CF}$ & BSLTx & 66 & 1.83 & 100 \\
\hline 2 & $M$ & 34 & HGG & BSLTx & 364 & 3.13 & 84 \\
\hline 3 & $\mathrm{~F}$ & 41 & PPH & HLTx & 198 & 2.52 & 100 \\
\hline 4 & $\mathrm{~F}$ & 23 & $\mathrm{CF}$ & BSLTx & 101 & 3.38 & 100 \\
\hline 5 & $M$ & 36 & $\mathrm{CF}$ & BSLTx & 74 & 1.98 & 100 \\
\hline 6 & $\mathrm{~F}$ & 34 & ES & $\begin{array}{l}\text { HLTx } \\
\text { HLT }\end{array}$ & 413 & $\begin{array}{l}1.90 \\
3.48\end{array}$ & 97 \\
\hline 7 & $\mathrm{~F}$ & 42 & ES & HLTx & 533 & 3.38 & 97 \\
\hline 8 & $\mathrm{~F}$ & 34 & $\begin{array}{l}\mathrm{ES} \\
\mathrm{ES}\end{array}$ & HLTx & 265 & $\begin{array}{l}3.00 \\
3.61\end{array}$ & $\begin{array}{r}9 l \\
100\end{array}$ \\
\hline & $M$ & 22 & $\mathrm{CF}$ & BSLTx & 183 & $\begin{array}{l}3.01 \\
3.72\end{array}$ & 100 \\
\hline 10 & $\mathrm{~F}$ & 40 & $\mathrm{BRN}$ & $\begin{array}{l}\text { DSLTx } \\
\text { BSLT }\end{array}$ & 186 & 2.12 & 100 \\
\hline 11 & $M$ & 37 & ES & HLTx & 1167 & 3.46 & 100 \\
\hline 12 & $\mathrm{~F}$ & 46 & BRN & BSLTx & 104 & 2.07 & 100 \\
\hline 13 & $\mathrm{~F}$ & 31 & $\mathrm{CF}$ & BSLTx & 276 & 2.90 & 90 \\
\hline 14 & $M$ & 39 & $\mathrm{CF}$ & BSLTx & 542 & 2.95 & 91 \\
\hline 15 & $M$ & 22 & ES & HLTx & 722 & 4.33 & 99 \\
\hline 16 & $\mathrm{~F}$ & 35 & PPH & BSLTx & 285 & 3.60 & 99 \\
\hline Mean (SD) & & $34.3(7.09)$ & & & $342.4(289.1)$ & $3.11(0.8)$ & $97.3(4.8)$ \\
\hline
\end{tabular}

$\mathrm{CF}=$ cystic fibrosis $\mathrm{HGG}=$ hypogammaglobulinaemia with bronchiectasis; $\mathrm{PPH}=$ primary pulmonary hypertension; $\mathrm{ES}=$ Eisenmenger's syndrome; BRN = bronchiectasis; BSLTx = bilateral sequential lung transplant; HLTx = heart and lung transplant; FEV $(\%$ best $)=\mathrm{FEV}_{1}$ expressed as a percentage of the best value after transplantation.

\section{Methods}

SUBJECT POPULATION

The characteristics of the subjects are given in table 1. Ten subjects had bilateral sequential lung transplants and six underwent heart-lung transplantation. Subjects were recruited 661167 days after transplantation, had stable lung function, and no signs of rejection or infection in the lung parenchyma at the time of testing. There were six men and 10 women with a mean (SD) age of 34.3 (7.1) years and a mean (SD) forced expiratory volume in one second $\left(\mathrm{FEV}_{1}\right)$ of $3.11(0.79)$ 1. Mean $\mathrm{FEV}_{1}$ expressed as a percentage of the best value following transplantation was 97.3 (4.8)\%. Two subjects (nos 4 and 9) had a history of mild asthma before transplantation. Written informed consent was obtained from all subjects and the protocol was approved by the Alfred Hospital ethics review committee.

The criteria for selection of pulmonary donors were in accord with published guidelines. ${ }^{18}$ Lung allografts came from donors without known lung disease (including chronic obstructive pulmonary disease and asthma). ABO matching, size matching and, where possible, CMV serological matching (IgG) were performed. The immunosuppressive protocols used were similar to those

Table 2 Immunosuppression therapy and biopsy findings

\begin{tabular}{llllll}
\hline $\begin{array}{l}\text { Patient } \\
\text { no. }\end{array}$ & $\begin{array}{l}\text { Cyclosporin } \\
(\mu g / l)\end{array}$ & $\begin{array}{l}\text { Imuran } \\
(\text { mg/day })\end{array}$ & $\begin{array}{l}\text { Azathiaprine } \\
\text { (mg/day) }\end{array}$ & $\begin{array}{l}\text { TBB } \\
\text { grading }\end{array}$ & $\begin{array}{l}\text { Micro- } \\
\text { organisms }\end{array}$ \\
\hline 1 & 360 & 15 & 75 & A0B0 & 0 \\
2 & 162 & 15 & 25 & A1B0 & 0 \\
3 & 195 & 15 & 125 & A1B2 & CMV, MRS \\
4 & 257 & 15 & 25 & A0B0 & 0 \\
5 & 820 & 20 & 125 & A1B2 & PSA, ASP \\
6 & 264 & 15 & 75 & A0B0 & 0 \\
7 & 134 & 7.5 & 50 & A1BX & 0 \\
8 & 264 & 15 & 75 & A0B0 & CMV \\
9 & 432 & 7.5 & 50 & A1BX & CMV \\
10 & 225 & 12.5 & 50 & A1B0 & 0 \\
11 & 265 & 7.5 & 50 & A0B0 & SPN \\
12 & 307 & 15 & 50 & A1BX & SA \\
13 & 710 & 20 & 50 & A1B2 & CMV \\
14 & 493 & 7.5 & 50 & A1B0 & PSA, CMV \\
15 & 243 & 7.5 & 100 & A0B0 & 0 \\
16 & 268 & 15 & 75 & A1B0 & -
\end{tabular}

Transbronchial biopsy (TBB) gradings: $\mathrm{A}=$ airways; $\mathrm{B}=$ bronchioles; $0-4=$ no rejection detectable through to rejection clearly present; $\mathrm{X}=$ not classifiable.

$\mathrm{CMV}=$ cytomegalovirus; PSA $=$ Pseudomonas aeruginosa $; \mathrm{MRS}=$ multi-resistant Staphylococcus $\mathrm{ASP}=$ Aspergillus $; \mathrm{SA}=$ Staphylococcus aureus $; \mathrm{SPN}=$ Streptococcus pneumoniae reported by other centres. ${ }^{1920}$ All subjects began triple immunosuppression therapy immediately after surgery (table 2 ).

EXPERIMENTAL DESIGN

Subjects attended the laboratory on the morning of a routine follow up bronchoscopic examination. A methacholine challenge was performed 1-2 hours before bronchoscopy. During bronchoscopy transbronchial (TBB) and endobronchial (EBB) biopsy samples were taken and bronchoalveolar lavage (BAL) was performed. Six days after the bronchoscopic examination subjects returned to the laboratory for a hypertonic saline challenge. Both challenges were performed in the morning to avoid potential confounding by diurnal variation. ${ }^{21}$

\section{METHACHOLINE AND HYPERTONIC SALINE} CHALLENGES

Baseline spirometric tests were performed prior to the challenge on a computerised rolling seal spirometer (SensorMedics 922, California, USA) to ATS criteria. ${ }^{22}$ The methacholine challenge was performed following a standard protocol ${ }^{23}$ using a MEFAR dosimeter and nebulisers (MB3 Bovezzi, Italy). The dose of methacholine required to produce a $20 \%$ fall in $\mathrm{FEV}_{1}\left(\mathrm{PD}_{20} \mathrm{M}\right)$ was calculated by linear interpolation between the last two doses on the dose-response curve. ${ }^{24}$ Hyperresponsiveness was defined as a $\mathrm{PD}_{20}$ of $2 \mathrm{mg}$ or less. The hypertonic saline challenge was performed following a standard protocol ${ }^{24}$ which was extended to include a cumulative dose of $60 \mathrm{ml}$. The amount of hypertonic saline required to produce a $15 \%$ fall in $\mathrm{FEV}_{1}\left(\mathrm{PD}_{15} \mathrm{HS}\right)$ was calculated by linear interpolation between the last two doses on the dose-response curve. ${ }^{24} \mathrm{~A}$ positive response was defined as a $\mathrm{PD}_{15}$ of $60 \mathrm{ml}$ or less. All subjects were given nebulised salbutamol and ipratropium bromide after both challenges, and ventilatory function was monitored until the $\mathrm{FEV}_{1}$ had returned to $90 \%$ of the baseline value. 


\section{BRONCHOSCOPY AND BRONCHOALVEOLAR}

LAVAGE

Fibreoptic bronchoscopy was performed after premedication with intravenous midazolam. Topical lignocaine (4\% to upper airways and $2 \%$ to lower airways) was used to anaesthetise the bronchial tree. Supplemental oxygen was provided continuously during the procedure and pulse oximetry monitored. After wedging the bronchoscope, usually in a subsegment of the middle lobe, three $60 \mathrm{ml}$ aliquots of phosphate buffered saline were instilled. The fluid was immediately aspirated into a siliconised container at a negative pressure of approximately $80 \mathrm{mmHg}$ and transported to the laboratory at $4^{\circ} \mathrm{C}$ for processing and analysis. Duplicate cytocentrifuge preparations were fixed in Carnoy's fluid for 45 minutes at ambient temperature and then incubated in $0.5 \%$ toluidine blue in $3 \%$ acetic acid for 10 seconds. Slides were washed in distilled water and an estimated 5000 cells were examined using a field scanning technique with light microscopy. Mast cells were identified through their content of granules which characteristically stain metachromatically with the toluidine blue used.

Total cell counts were performed on the unfiltered BAL fluid using a modified Neubauer haemocytometer. Differential cell counts (\%) were made on duplicate cytospin preparations using $200 \mathrm{ml}$ of unfiltered BAL aspirate (Shandon Cytospin III, $850 \mathrm{rpm}, 10$ minutes) stained with Quick-Diff. A total of 1000 cells was counted. The product of the differential and total cell counts was used to calculate absolute BAL cell counts.

Following BAL, four endobronchial biopsy (EBB) specimens were taken from each of the right upper and lower subcarinae using alligator forceps (Olympus FB 15C, Japan). Transbronchial biopsy (TBB) specimens were then taken from the right upper lobe, middle lobe, and lower lobe and graded to exclude active acute rejection. ${ }^{25} \mathrm{EBB}$ specimens, embedded in OCT (a glycerol based freezing matrix: Sigma), were snap frozen in a liquid $\mathrm{N}_{2}$-chilled isopentane slurry, then sectioned on a high performance cryostat immediately or after storage at $-80^{\circ} \mathrm{C}$. Tissue processing and quantification of cell markers was carried out using a modification of a standard technique described previously. ${ }^{26}$

For each monoclonal antibody or isotype control two EBB sections $30 \mathrm{~mm}$ apart were examined by a single experienced observer (CW) blinded to the results of the physiological investigations. The submucosa was analysed to a depth of $150 \mathrm{~mm}$ below the basement membrane in five non-overlapping high power fields using a computerised colour image analysis system (Video Pro 32, Leading Edge, Sydney, Australia). Only nucleated stained cells were counted as positive and cells within vascular spaces were excluded. Counts were expressed per mm basement membrane. TBB specimens were graded for rejection by a pathologist in the Anatomical Pathology Department of the hospital.

\begin{tabular}{llll}
$\begin{array}{l}\text { Table } 3 \\
\text { results }\end{array}$ & \multicolumn{3}{l}{ Methacholine and hypertonic saline challenge } \\
\hline $\begin{array}{l}\text { Patient } \\
\text { no. }\end{array}$ & Transplantation & $\begin{array}{c}\text { Methacholine } \\
\text { type }\end{array}$ & $4.5 \%$ saline \\
\hline PD $(\mathrm{mg})$ & $P D_{15} H S(\mathrm{ml})$ \\
\hline 1 & BSLTx & 0.266 & 2.3 \\
2 & BSLTx & 0.113 & 33 \\
3 & HLTx & 0.474 & $>60$ \\
4 & BSLTx & $>2.0$ & $>60$ \\
5 & BSLTx & 0.075 & $>60$ \\
6 & HLTx & $>2.0$ & $>60$ \\
7 & HLTx & $>2.0$ & $>60$ \\
8 & HLTx & $>2.0$ & $>60$ \\
9 & BSLTx & 1.849 & $>60$ \\
10 & BSLTx & 0.544 & $>60$ \\
11 & HLTx & 0.024 & $>60$ \\
12 & BSLTx & 0.202 & $>60$ \\
13 & BSLTx & 0.041 & 51.5 \\
14 & BSLTx & $>2.0$ & $>60$ \\
15 & HLTx & $>2.0$ & $>60$ \\
16 & BSLTx & $>2.0$ & $>60$ \\
Mean* & & 0.18 & 15.75 \\
\hline
\end{tabular}

BSLTx $=$ bilateral sequential lung transplant; HLTx $=$ heart and lung transplant.

* Geometric mean for responders only.

STATISTICAL ANALYSIS

Statistical analyses were made using SPSS for Windows (Release 6.0) and Minitab (Release 7.1). All $\mathrm{PD}_{20} \mathrm{M}$ values were logarithmically transformed prior to analysis. Differences in cellular indices were tested using the MannWhitney test (after data failed a test for normality). Spearman's rank correlation was used to test relationships between measured variables, with cell counts analysed in absolute units. A $\chi^{2}$ test was used for comparisons between two categorical variables.

\section{Results}

METHACHOLINE CHALLENGE

Nine of the 16 subjects studied (56\%) were hyperresponsive to methacholine (table 3), covering the spectrum of responsiveness from severe to mild. $\mathrm{PD}_{20} \mathrm{M}$ was not related to the time after transplantation, pre-challenge $\mathrm{FEV}_{1}$, or $\mathrm{FEV}_{1}$ expressed as a percentage of the best value after transplantation. Seven of the nine subjects responsive to methacholine were bilateral sequential lung transplant recipients and the two subjects with a history of asthma prior to transplantation (nos 4 and 9) were not among the most responsive.

\section{HYPERTONIC SALINE CHALLENGE}

Only three of the 16 subjects studied (19\%) responded to hypertonic saline and two of these had weak responses with $\mathrm{PD}_{15} \mathrm{HS}$ of $>20 \mathrm{ml}$ (table 3). All three subjects responsive to hypertonic saline were bilateral sequential lung transplant recipients and were also hyperresponsive to methacholine. There was no obvious relationship between $\mathrm{PD}_{15} \mathrm{HS}$ and the time after transplantation, pre-challenge $\mathrm{FEV}_{1}$, or $\mathrm{FEV}_{1}$ expressed as a percentage of the best value after transplantation.

Heart-lung transplant recipients were not more sensitive than bilateral sequential lung transplant recipients to either methacholine or hypertonic saline. Because of the small number of subjects responsive to hypertonic saline we were unable to compare $\mathrm{PD}_{15} \mathrm{HS}$ with any other parameter measured. 
Table 4 Numbers* of inflammatory cells in bronchoalveolar lavage fluid

\begin{tabular}{lccc}
\hline Cell type & $P D_{20} M<2.0 m g(n=9)$ & $P D_{20} M>2.0 m g(n=6)$ & $p$ value \\
\hline Mast cells & $56(52-127)$ & $31(0-54)$ & 0.05 \\
Eosinophils & $0(0-340)$ & $155(0-390)$ & $>0.05$ \\
Lymphocytes & $27280(16305-97380)$ & $29570(10010-81630)$ & $>0.05$ \\
\hline
\end{tabular}

* Median (interquartile range) number of cells per ml BAL aspirate.

$\mathrm{PD}_{20} M=$ dose of methacholine required to produce a $20 \%$ fall in $\mathrm{FEV}_{1}(\mathrm{mg})$.

Table 5 Numbers* of inflammatory cells in endobronchial biopsy specimens

\begin{tabular}{lccc}
\hline Cell type & $P D_{20} M<2.0 m g(n=9)$ & $P D_{20} M>2.0 m g(n=6)$ & $p$ value \\
\hline Mast cells & $4(2-7)$ & $11.5(6.0-17.3)$ & 0.049 \\
Eosinophils (total) & $15(0-27)$ & $12.5(7.5-23)$ & $>0.05$ \\
Eosinophils (activated) & $2(1-10)$ & $9.0(1.5-10.5)$ & $>0.05$ \\
Lymphocytes & $68(41-110)$ & $88.5(48.3-176.3)$ & $>0.05$ \\
\hline
\end{tabular}

* Median (interquartile range) number of cells per mm of basement membrane.

$\mathrm{PD}_{20} \mathrm{M}=$ dose of methacholine required to produce a $20 \%$ fall in $\mathrm{FEV}_{1}(\mathrm{mg})$.

\section{BRONCHOSCOPY AND BRONCHOALVEOLAR}

LAVAGE

BAL fluid and biopsy specimens were available for analysis in 15 of the 16 subjects studied (94\%; tables 4 and 5). All TBB specimens were grade 0 or $1,{ }^{25}$ excluding active acute rejection (table 2). Eight subjects had airways colonised with micro-organisms, but none were considered to have active infection (table 2).

There was no significant difference in the numbers of lymphocytes in the BAL fluid and EBB specimens in subjects responsive to methacholine and those unresponsive to methacholine, with a median of 27280 cells $/ \mathrm{ml}$ BAL fluid for responders (interquartile range 16 305-97 380) and 29570 for non-responders (10 010-81 630), $\mathrm{p}=0.68,96 \%$ confidence interval (CI) -48200 to 77630 ) and 68 cells/ $\mathrm{mm}$ basement membrane in EBB specimens for responders (41-110) versus 88.5 cells $/ \mathrm{mm}$ for non-responders (48.3-176.3), $\mathrm{p}=0.44$, $96 \%$ CI -120.0 to 36.9 .

The numbers of eosinophils in the BAL fluid were not significantly different between responders and non-responders to methacholine with a median of $0(0-340)$ cells $/ \mathrm{ml}$ BAL fluid for responders and $155(0-390) / \mathrm{ml}$ for nonresponders $(\mathrm{p}=0.53,96 \%$ CI -280.0 to 200.2). There was no significant difference between these subject groups in total or activated eosinophils in EBB specimens with a median of $15(0-27)$ total cells $/ \mathrm{mm}$ basement membrane in responders and $12.5(7.5-23) /$ $\mathrm{mm}$ in non-responders $(\mathrm{p}=1.0,96 \%$ CI -18.01 to 19.0$)$ and $2(1-10)$ activated cells/ $\mathrm{mm}$ basement membrane in EBB specimens from responders compared with $9.0(1.5-10.5) /$ $\mathrm{mm}$ from non-responders $(\mathrm{p}=0.59,96 \% \mathrm{CI}$ -9.0 to 5.0 ). The lymphocyte and eosinophil numbers in BAL fluid and EBB specimens did not correlate with $\log _{10} \mathrm{PD}_{20} \mathrm{M}$.

Subjects responsive to methacholine had more mast cells in BAL fluid than non-responders with a median of $56(52-127)$ cells/ ml BAL fluid compared with $31(0-54)$ for nonresponders ( $p=0.05,96 \%$ CI 0.0 to 123.9$)$, but paradoxically fewer mast cells in EBB specimens with a median of $4(2-7)$ cells $/ \mathrm{mm}$ basement membrane in responders compared with $11.5(6.0-17.25)$ in non-responders $(\mathrm{p}=0.049$, $96.1 \% \mathrm{CI}-15.0$ to 0.0 ). There was a negative correlation between $\log _{10} \mathrm{PD}_{20} \mathrm{M}$ and the num- ber of mast cells in EBB specimens $(p=0.016)$ - that is, the more hyperresponsive subjects had fewer mast cells.

\section{Discussion}

This study is the first to investigate responsiveness to hypertonic saline in clinically stable lung transplant recipients, to compare these findings with responsiveness to methacholine, and to relate BHR to airway wall inflammation. We found that, while only three subjects responded to hypertonic saline, most were responsive to methacholine. $\mathrm{PD}_{20} \mathrm{M}$ was not related to the time after transplantation, pre-challenge $\mathrm{FEV}_{1}$, or $\mathrm{FEV}_{1}$ expressed as a percentage of the best value after transplantation. Previous studies have also found lung transplant recipients to be responsive to methacholine ${ }^{1-6}$ and unresponsive to physical stimuli. ${ }^{67}$ The subjects with a history of mild asthma prior to transplantation (nos 4 and 9) were by no means the most sensitive. In fact, subject 4 was only mildly responsive to methacholine and unresponsive to hypertonic saline and subject 9 was unresponsive to both methacholine and hypertonic saline. Heart-lung transplant recipients were not more sensitive than bilateral sequential lung transplant recipients.

Responsiveness to methacholine is not necessarily accompanied by responsiveness to hypertonic saline in asthmatic subjects. Usually subjects with moderate to severe responsiveness to methacholine ( $\mathrm{PD}_{20} \mathrm{M}$ of $<0.4 \mathrm{mg}$ ) respond to hypertonic saline. ${ }^{1617}$ It is generally accepted that methacholine and hypertonic saline act differently to cause the bronchoconstriction associated with BHR. In asthmatic subjects methacholine is thought to act directly on airway smooth muscle muscarinic (M3) receptors. After lung transplantation denervation hypersensitivity of muscarinic receptors is thought to be responsible for $\mathrm{BHR},{ }^{127}$ although subjects with reduced vagal tone have failed to show BHR. ${ }^{27}$ Hypertonic saline is thought to act indirectly through the release of mediators from inflammatory cells, especially mast cells. ${ }^{1617}$ Studies in asthmatic subjects have linked BHR to inflammatory cells in BAL fluid and EBB specimens. ${ }^{9-15}$ However, we found no relationship between BHR and hypertonic saline or airway inflammation in our subjects, although they did have increased inflammatory cell numbers despite triple immunosuppression.

Only three studies reported in the literature have looked at physical stimuli in lung transplant recipients - namely, ultrasonically nebulised distilled water (USNDW), ${ }^{1}$ exercise,${ }^{5}$ and isocapnic dry air hyperventilation. ${ }^{6}$ USNDW and exercise are closely correlated in asthmatic subjects ${ }^{1617}$ but in lung transplant recipients mild BHR to USNDW has been reported only during lung parenchymal rejection while no change in $\mathrm{FEV}_{1}$ has been observed after exercise. Isocapnic dry air hyperventilation also failed to produce a response in lung transplant recipients. 
There have been few studies relating inflammatory changes to BHR in lung transplant recipients. Maurer et $a l^{3}$ reported on BHR to methacholine and histamine in bilaterally (heart-lung and double lung transplant) and unilaterally (single lung transplant) denervated subjects. No subject had a history of asthma prior to transplantation and bronchial mucosal biopsies were obtained for most subjects in this study. They found that bilaterally denervated subjects were significantly more responsive to both methacholine and histamine than unilaterally denervated subjects. Minimal airway inflammatory changes were noted empirically in only three of the 14 subjects studied, although this was not formally quantified. Herve et $a l^{6}$ performed methacholine and isocapnic dry air hyperventilation challenges on heartlung, double lung, and single lung transplant recipients with normal lung histology, no prior history of asthma, and no lung or bronchial infection. Their results were compared with asthmatic subjects and normal controls and found to be similar to the normal control subjects. They suggested that previous studies reporting BHR to methacholine following lung transplantation may have included subjects with undiagnosed rejection or infection. However, our subjects and those studied by Maurer et al were free of infection and lung rejection at the time of testing and still responded to methacholine.

Higenbottam et $a l^{1}$ reported a study in which heart-lung transplant recipients underwent methacholine and USNDW challenges along with TBB. This study differed from the others in that they included subjects with a history of asthma prior to transplantation (seven out of 10) and subjects experiencing periods of acute lung rejection. TBB specimens of lung parenchyma were studied for signs of inflammation and the presence of eosinophils. Most of the subjects were hyperresponsive to methacholine, but this was not related to the presence of eosinophils or inflammation in the TBB specimens. Mild responsiveness to USNDW was recorded in six of the 16 subjects studied, typically during an episode of acute rejection or when there was evidence of inflammation in the TBB specimen. There did not appear to be a relationship between a history of asthma prior to transplantation and BHR to either stimulus, although BHR to USNDW appeared to be related to acute lung rejection. In this study challenges were performed only 48 hours apart and it is possible that the first challenge (methacholine) could have affected the second challenge (USNDW).

Higenbottam et al included subjects currently experiencing rejection and those with a history of asthma. Their subjects were more responsive to physical stimuli than ours, which strengthens their suggestion that BHR to physical stimuli is related to acute lung rejection and explains why our stable subjects were almost all unresponsive. We feel that, overall, the findings of our study are consistent with the earlier work discussed. Of all the markers studied, only mast cell numbers correlated weakly with BHR, and then only to BHR to methacholine. The re- lationship between BHR to methacholine and mast cells is difficult to interpret as there was a positive relationship between mast cell numbers in BAL fluid and BHR, but a negative one between mast cell numbers in EBB specimens and BHR. Overall, we found no clear relationship between BHR to methacholine and inflammatory cells in BAL fluid or airway or lung biopsy specimens, which disagrees with the previously described work in asthma.

Although the number subjects responding to hypertonic saline in our study population was small, we may be able to complement Higenbottam's observation of a relationship between USNDW BHR and acute rejection. Our study used hypertonic saline rather than USNDW because it has been used more extensively in clinical asthma studies and is now the nonisotonic aerosol of choice. ${ }^{24}$ It is of interest to note that the only subjects in our study who subsequently developed bronchiolitis obliterans syndrome (BOS) were the three subjects with hypertonic saline reactivity at the time of the study. No subject had any change in lung function for at least three months following testing, but with an average follow up of 560 days there has been one death from BOS (subject 2 at 553 days after transplantation) and two subjects (1 and 13) have since been classified BOS grades 1 and 3. This observation warrants a prospective study of a larger recipient population to determine at what point hypertonic saline reactivity is acquired and the subsequent outcome.

In conclusion, this study found no convincing evidence that airway inflammation, as assessed by numbers of mast cells, eosinophils, and lymphocytes in BAL fluid and EBB specimens, is related to BHR to either methacholine or hypertonic saline. This suggests that there may be an alternative mechanism causing BHR following lung transplantation from the one associated with asthma. Denervation hypersensitivity may possibly explain the methacholine reactivity, but a different unknown mechanism is responsible for the hypertonic saline reactivity. Methacholine reactivity seems to be unimportant clinically, but hypertonic saline reactivity may yet prove relevant to the development of BOS.

This study was supported by the Alfred Hospital Foundation.

1 Higenbottam T, Jackson M, Rashdi T, Stewart S, Coutts C, Wallwork J. Lung rejection and bronchial hyperresposiveness to methacholine and ultrasonically nebulised distilled water in heart-lung transplant subjects. $A m$ Rev Respir Dis 1989;140:52-7.

2 Glanville AR, Theodore J, Baldwin JC, Robin ED. Bronchia responsiveness after human heart-lung transplantation. Chest 1990;97:1360-6.

3 Maurer JR, Mclean PA, Cooper JD, Chamberlain DW, Grossman RF, Zamel N. Airway hyperreactivity in subjects undergoing lung and heart-lung transplantation. Am Rev Respir Dis 1989;139:1038-41.

4 Banner NR, Heaton R, Hollingshead L, Guz A, Yacoub MH. Bronchial reactivity to methacholine after combined MH. Bronchial reactivity to methacholine after com

5 Glanville AR, Burke CM, Theodore J, Baldwin JC, Harvey $\mathrm{J}$, Vankessel A, et al. Bronchial hyper-responsiveness after human cardiopulmonary transplantation. Clin Sci 1987; 73:299-303.

6 Herve P, Picard N, Le Roy Ladurie M, Silbert D, Cerrina J, Le Roy Ladurie F, et al. Lack of bronchial hyperresponsiveness to methacholine and to isocapnic dry air hyperventilation in heart/lung and double lung transplant recipients with normal lung histology. Am Rev Respir Dis 1992;145:1503-5. 
7 Glanville AR, Gabb G, Theodore J, Robin ED. Bronchial hyper-responsiveness after human bronchial responsiveness to exercise after cardiopulmonary transplantation. Chest 1989;96:281-6.

8 Boushey HA, Holtzman MJ, Sheller JR, Nade JA. State of the art. Bronchial hyperreactivity. Am Rev Respir Dis 1980; 121:389-413.

9 Corrigan CJ, Kay AB. The roles of inflammatory cells in the pathogenesis of asthma and chronic obstructive in the pathogenesis of asthma and chronic obstructive

pulmonary disease. Am Rev Respir Dis 1991;143:1165-8.
10 Busse WW, Calhouin WF, Sedgwick JD. Mechanism of airway inflammation in asthma. Am Rev Respir Dis 1993; 147:S20-4.

11 Wardlaw AJ, Dunnette S, Gleich GJ, Collins JV, Kay AB. Eosinophils and mast cells in bronchoalveolar lavage in subjects with asthma. Am Rev Respir Dis 1988;137:62-9.

12 Kelly C, Ward C, Stenton CS, Bird G, Hendrick DJ, Walters EH. Number and activity of inflammatory cells in bronchoalveolar lavage fluid in asthma and their relation to airway responsiveness. Thorax 1988;43:684-92.

13 Jeffery PK, Wardlaw AJ, Nelson FC, Collins JV, Kay AB. Bronchial biopsies in asthma. An ultrastructural, quanBronchial biopsies in asthma. An ultrastructural, quan-
titative study and correlation with hyperreactivity. Am Rev Respir Dis 1989;140:1745-53.

14 Capri S, Marini M, Vittori E, Vassalli G, Mattoli S. Bronchoconstrictive responses to inhaled ultrasonically nebulised distilled water and airway inflammation in asthma. Chest 1993;104:1346-51.

15 Chetta A, Foresi A, DelDonno M, Consigli GF, Bertorelli G, Pesci A, et al. Bronchial responsiveness to distilled water and methacholine and its relationship to inflammation and remodelling of the airways in asthma. Am F Respir Crit Care Med 1996;153:910-7.

16 Smith CM, Anderson SD. Inhalation provocation tests using nonisotonic aerosols. f Allergy Clin Immunol 1989;84: 781-90.
17 Anderson SD, Smith CM. Osmotic challenges in the assessment of bronchial hyperresponsiveness. Am Rev Respir Dis 1991;143:S43-6.

18 Griffith BP, Zenati M. The pulmonary donor. Clin Chest Med 1990;11:217-27.

19 Cooper JD, Pearson FG, Patterson GA. Technique of successful lung transplantation in humans. F Thorac Car diovasc Surg 1987;93:173-81.

20 Cooper JD, Patterson GA, Trulock EP, and the Washington University Lung Transplant Group. Results of single and bilateral lung transplantation in 131 consecutive recipients. F Thorac Cardiovasc Surg. 1994;107:460-71.

21 Morrison JFJ, Higenbottam TW, Hathaway TJ, Clelland C, Scott JP, Wallwork J. Diurnal variation in FEV 1 after heartlung transplantation. Eur Respir f 1992;5:834-40.

22 American Thoracic Society. Standardization of spirometry: 1994 update. Am f Respir Crit Care Med 1995;152:110737.

23 Burney PGJ, Luczynska C, Chinn S, Jarvis D. The European Community Respiratory Health Survey. Eur Respir 71994 ; 7:954-60.

24 Sterk PJ, Fabbri LM, Quanjer PhH, Cockroft DW, O'Byrne PM, Anderson SD, et al. Airway responsiveness. Standardised challenge testing with pharmacological, physical and sensitizing stimuli in adults. Eur Respir f 1993;6(Suppl 16):53-83.

25 Youssem SA, Berry GJ, Brunt EM. A working formulation for the standardisation of nomenclature on the diagnosis .

26 Booth H, Richmond I, Ward C, Gardiner PV, Harkawat R, Walters EH. Effect of high dose fluticasone propionate on airway inflammation in asthma as assessed by bronchoalveolar lavage and endobronchial biopsy. Am f Respir Crit Care Med 1995;152:45-52.

27 Heaton RW, Guy RJC, Gray BJ, Watkins PJ, Costello JF Diminished bronchial reactivity to cold air in diabetic
patients with autonomic neuropathy. BMF 1984;289:14951. 